\title{
COMPARISON OF QUALITY OF LIFE IN GIRLS IN RE-EDUCATION FACILITIES IN SLOVAKIA AND POLAND
}

\author{
Jarmila Žolnová, Veronika Vaňugová
}

\begin{abstract}
The study investigates the quality of life in adolescent girls ( $N$ 97) with psychosocial disabilities committed to the re-education facilities in Slovakia and Poland. More specifically, we focus on comparison of the cognitive evaluation of life as a whole. In order to determine life satisfaction or dissatisfaction we used the exploratory Life Satisfaction Questionnaire composed by Fahrenberg, Myrtek, Schumacher, and Brähler (2001). The collected data were then analysed using a t-test showing that the girls were neither satisfied nor dissatisfied with their life cycle in the re-education facilities, without any significant differences.
\end{abstract}

\section{Keywords}

life satisfaction, girls, re-education, Slovakia, Poland

\section{Introduction}

Special educational facilities in Slovakia include therapeutic and educational sanatoria, diagnostic centres, and re-education centres. A child is placed in the re-education centre based on a court decision or at the request of the child's legal representative.

The definition of the re-education centres can be found in the Section 122 of the Act No. 245/2008 on Upbringing and Education (School Act) and on amendments and supplements to certain Acts as amended. They are defined as special educational facilities that provide children up to the age of eighteen, with an option to prolong their stay by another year, with the upbringing and education inclusive of a vocational training. The purpose of re-education centres is to re-integrate a child into his or her original social environment using special upbringing and educational program and individual re-education program. 
In Poland, the special educational facilities include shelters for minors (in Polish language schroniska dla nieletnich), youth educational centres (in Polish language młodziezowe ośrodki wychowawcze), correctional institutions (in Polish language zakłady poprawcze) and juvenile correctional facilities (in Polish language zakłady karne dla młodocianych). A child, who has been showing a lower degree of demoralization, has committed a minor criminal offence or is unable to adjust to the norms of the society she or he belongs to, can be committed to a youth educational centre upon the decision of the court, in cooperation with the shelter for minors and the Centre for Education Development (in Polish language Ośrodek Rozwoju Edukacji), or at the request of child's legal representative. The purpose of these facilities is upbringing, re-education, and re-socialization of a child. The main goal is to eliminate the causes and symptoms of social maladaptation. In addition, evenly important is to achieve such change in a child's behaviour so that he or she can be integrated back into the everyday life respecting the societal norms. Placement in the special educational facility is not the kind of life events that a child accepts willingly. It is an order from the state or legal representative of those children. The children lose their friends, their lifestyle changes and they feel uncomfortable.

In the years 2013 and 2014, the Public Defender of Rights in Slovakia carried out an internal analysis with the focus on the system of re-education. The final reports revealed some shortcomings in the re-education process and material and technical equipment of the centres. Based on the motivational interview, a child is allocated to a study programme at the secondary vocational school that provides the same programme as the school at the re-education centre.

Websites of the particular re-education centres provide the information about the study programmes that girls can attend, e.g. horticulture, agriculture, textile production, dressmaking, and custom sewing. In addition to these programmes, girls in Poland can also study to become a cook or a waitress; hairdresser and they can also study at the grammar schools or vocational schools outside of the re-education facility. The Public Defender of Rights further criticized the fact that educators in the re-education centres do not encourage independence in these children. Locating this kind of facilities on the outskirts of towns and villages does not help either. Children are provided with ready food, daily program, their leisure time is filled with a broad range of activities, and so when they leave the facility they are unable to integrate into common everyday life. On the contrary, the Polish re-education system introduced special boarding houses, falling under the authority of youth educational centres, providing the young persons with the possibility to live there before leaving the re-education centre. They are under a low level of direct supervision with open regime. Girls are responsible for their own shopping and cleaning, they attend various cultural and sporting events. They also free to search for a job and their own place to live.

Using the modified model of the intercultural project WHOQOL (World Health Organization Quality of Life), the presented study seeks to evaluate the differences in how the adolescent girls in the re-education centres and youth educational centres see the particular domains determining their quality of life. The WHOQOL introduces the following domains and sub-domains: physical health (energy and fatigue, sleep and rest, 
pain and discomfort); psychological health (positive feelings, negative feelings, selfesteem, thinking, learning, memory and concentration, bodily image and appearance); level of independence (mobility, activities of daily living, dependence on medical substances and medical aids, work capacity); social relationship (personal relationships, social support and sexual activity); environment ( financial resources, health and social care, freedom, physical safety and security, physical environment, opportunities to acquire new information and skills, transport) and spiritual domain ( religion, spirituality and personal beliefs) (Babinčák, 2008, p. 37). The quality of life encompasses cultural and spiritual dimension and as such, it is perceived subjectively. The quality of life refers to our good feeling, well-being, and satisfaction with all around us (Masárová, 2012).

At the same time, we look at the assessment of global life satisfaction and the possible differences based on the nationality of the surveyed girls.

Assessing one's own life is very individual and it is conditioned by the complexity of a one's life. Veenhoven's model (Babinčák, 2008, In Bačová 2008, p. 56) shows that the chances of a good life need not mean a good life. Based on this model, the quality of life is divided into four quadrants. Liveability of the environment is defined by good living conditions. Life-ability of the person includes adaptive potential, health, capabilities of the person and so on. Utility of life shows that a good life must be good for something more than itself. It enriches the environment and people that the person associates with. Joy in life is a subjective appreciation of one's own life.

Global life satisfaction is a cognitive assessment of life as a whole (Dieder, 1994, In Mcknight, Huebner, \& Suldo, 2002). Minors who are committed to the re-education facility see this event as a radical and negative change in their lives. Suddenly, there is someone else who decides the direction of their life journey. The young people feel cheated when they realize that the verbal threats became reality. The formal procedure surrounding the placement, although different in both countries, is not the primary factor determining how the children feel about this life-changing event. The more important indicator is the refusal to accept the formal decision. The placement is an external decision the girls simply do not agree with. Therefore, we assume that the global life assessment will be identical among the girls from both groups and that they will present the tendency towards dissatisfaction with their current life.

The aim of the research is to offer a global comparison of the subjective assessments of the quality of life among the girls in the re-education centres in Slovakia and the youth educational centres in Poland. At the same time, we want to establish how the particular domains determining the quality of life affect its global assessment.

\section{Methodological procedure}

To achieve the aim of the research we used an exploratory questionnaire method. The measuring tool was a questionnaire designed to establish the quality of life. The life satisfaction questionnaire was designed by Fahrenberg, Myrtek, Schumacher and Brähler 
(2001). Rodná and Rodný (2001) translated the questionnaire into the Czech language and Testcentrum published it in Prague in the same year. Žolnová, Višňovská and Majherová (2015) modified the questionnaire so that it reflected the needs of the research into life satisfaction of students at the mainstream secondary vocational schools and students at the secondary vocational schools under the authority of re-education centres. Our modified questionnaire comprised eight categories: Health; Future profession training; Financial and material security; Leisure time; Sexuality; Self-satisfaction; Friends, acquaintance and family; Living. Each category contains seven statements. For each of these seven statements respondents indicated their preference by marking the most suitable level of satisfaction. The level of satisfaction or dissatisfaction with the statements in each of the eight categories was marked on the Likert scale. The following numerical points described the levels of satisfaction: 1 - very dissatisfied, 2 - dissatisfied, 3 - more dissatisfied than satisfied, 4 neither satisfied nor dissatisfied, 5 - more satisfied than dissatisfied, 6 - satisfied, 7 - very satisfied. In each category, the respondent could score the maximum of forty-nine and the minimum of seven points. Following the questionnaires, we used t-test to calculate the statistical significance between the particular items of the eight categories defining the quality of life as well as to compare the categories of the quality of life. We established the statistically significant differences at the $0.05(p<0.05)$ a $0.01(p<0.01)$ level of significance. In order to collect the data from the Polish re-education facilities, we had the questionnaire of life satisfaction translated into the Polish language.

The collection of the data took place in the facilities of both countries from June 2016 until January 2017. Prior to questionnaire administration, we obtained a written consent from all directors of the re-education centres and youth educational centres. We collected the data personally upon our visits to these establishments.

\section{Research sample}

The sample comprised 97 (100\%) girls from the re-education centres and youth educational centres, where $48(49 \%)$ of the girls were from the centres in Slovakia and $49(51 \%)$ of the girls were from the Polish youth educational centres. The respondents were all in the age group of fifteen to nineteen years of age, with an average age 16.1 in Slovakia and 16.9 in Poland. All respondents were in the re-education executive process for the minimum of six months or more.

\section{Description and data comparison}

We analysed and compared the particular domains determining the quality of life and the level of global life satisfaction in girls based on their nationality. We then evaluated the results of total arithmetic means for the individual domains of the quality of life, statistical differences, and t-tests from both samples (See Table 1). 
Table 1 Global life satisfaction: data analysis and comparison in the domains of quality of life

\begin{tabular}{|l|c|c|c|c|c|}
\hline \multirow{2}{*}{ Domain } & \multicolumn{2}{|c|}{ A.M } & \multicolumn{2}{c|}{ S.D. } & t-test \\
\cline { 2 - 5 } & SR & PL & SR & PL & \\
\hline Health & 4.12 & 3.91 & 1.38 & 1.11 & 0.40 \\
\hline Future profession training (school) & 4.79 & 4.88 & 1.49 & 1.18 & 0.77 \\
\hline Financial and material security & 4.54 & 4.90 & 1.58 & 1.29 & 0.25 \\
\hline Leisure time & 4.60 & 3.93 & 1.63 & 1.63 & 0.12 \\
\hline Sexuality & 4.74 & 4.90 & 1.45 & 1.13 & 0.53 \\
\hline Self-satisfaction & 4.82 & 4.61 & 1.62 & 1.47 & 0.49 \\
\hline Family, friends, acquaintances & 5.37 & 5.28 & 1.66 & 1.34 & 0.79 \\
\hline Living & 4.47 & 4.63 & 1.64 & 1.55 & 0.43 \\
\hline Total & 4.68 & 4.56 & 0.36 & 0.48 & 0.81 \\
\hline
\end{tabular}

(Source: own elaboration)

${ }^{*}-p<0.05,{ }^{* *}-p<0.01$

\section{Legend:}

A.M. - arithmetic mean, S.D. - statistical difference, SR - sample of girls from Slovakia, $P L$ - sample of girls from Poland

The table shows that the girls in Slovakia and Poland are almost equally satisfied with the domain of Health. The Slovak girls are, by two-tenths, just slightly more satisfied (4.12; 3.91) than the girls from Poland. In the domain Future profession training, the Polish girls are, on average, by one-tenth, slightly more satisfied than the Slovak girls (4.79; 4.88). In the domain Financial and material security, the Polish girls are more satisfied by four-tenths $(4.54 ; 4.90)$. The girls from Poland indicate also higher satisfaction with their sexuality - on average by two-tenths $(4.74 ; 4.90)$. The girls from Slovakia, however, are more satisfied with themselves in comparison to their Polish peers $(4.82 ; 4.61)$. In the domain Family, friends and acquaintance $(5.37 ; 5.28)$, the Slovak girls are by onetenth more satisfied, while in the domain Living $(4.47 ; 4.63)$, the Polish girls were more satisfied. In the domain Leisure time $(4.60 ; 3.93)$, we recorded the greatest difference. The girls from Slovakia were more satisfied by seven-tenths, however, it difference is still not statistically significant.

The mean values indicate that the girls from Slovakia and Poland are the least satisfied with the domain of Health. The girls from Poland assessed the domain of Leisure time equally negatively. The most positive responds were recorded in the domain Family, friends and acquaintance, both in Slovakia and Poland. The girls in the re-education centres in Slovakia and in youth educational centres in Poland were indecisive about their 
satisfaction with their present situation concerning health, future job training, financial security, living arrangements, leisure time activities, sexuality, own Self and family and friends ties (they indicated neither satisfied nor dissatisfied on the questionnaire scale). The Slovak girls are, on average, approximately by one-tenth, more satisfied.

By comparing the mean values in global life satisfaction (Slovak girls: 4.56 and Polish girls: 4.68), we can conclude that the girls assess their life satisfaction indifferently, that is by marking neither satisfied nor dissatisfied on the Likert scale (See Graph 1).

\section{Graph 1 Global life satisfaction of girls}

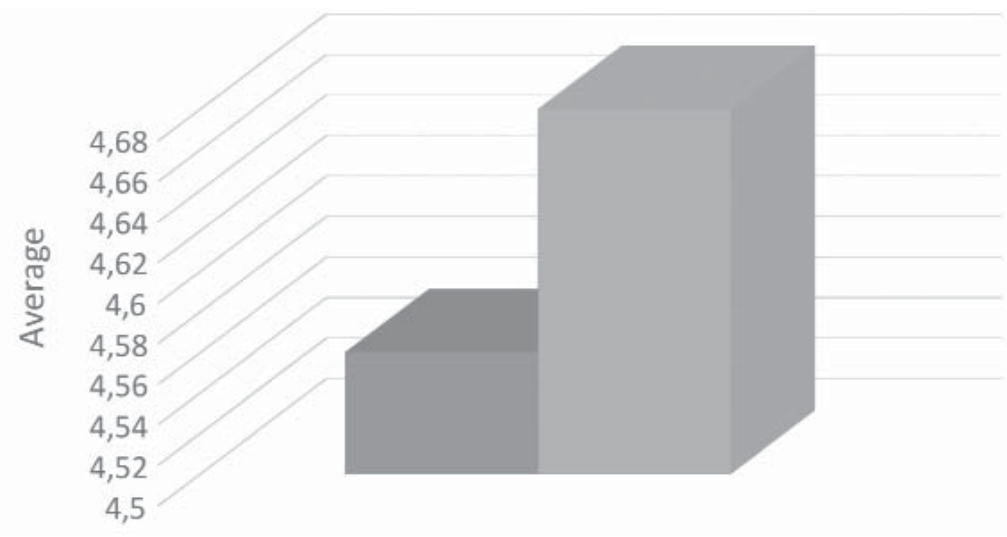

(Source: own elaboration)

Based on the mean values we have concluded that the girls of adolescent age, regardless of their nationality, are in general indecisive when it comes to their life satisfaction. T-test showed no significant differences between the two groups in the global assessment of life satisfaction or in assessment of particular domains determining the quality of life.

\section{Conclusion}

The study aimed to present the assessment of eight domains determining global quality of life from the perspective of adolescent girls committed to the re-education centres in Slovakia and youth educational centres in Poland. The study offers mean values calculated from the statements of ninety-seven girls. The results show that girls from Slovakia and Poland indicated that they felt indecisive about their life satisfaction or dissatisfaction in the domain Health, Future profession training, Financial and material security, Leisure time, Sexuality, Self-satisfaction, and Living arrangements (point 4 on the Likert scale). The girls were rather satisfied than dissatisfied (point 5 on Likert scale) with their family 
ties and friendships. Indecisiveness in global satisfaction with life (point 4 on the Likers scale) is identical for the both groups of girls.

Indefinite global assessment of life in the system of re-education asks for changes which (Ungar 2005, In Lukšík, Hargašová, Kuruc, Lukšíková, 2014) describes as critical. Factors that are crucial for successful implementation of these changes are stability and continuity of the system; development of reading literacy; parents or guardians recognizing education as a key to a better life; friends outside of family circles who were and are successful at school; after school activities fostering development of social skills. The empirical findings can be of a practical use in the facilities where we conducted our research. Together with other diagnostic methods known to special pedagogy, the questionnaire could be used as another diagnostic instrument with the purpose to evaluate the dynamics of the re-education process.

\section{References}

Bačová, V. (2008). Kvalita života a sociálny kapitál. [Quality of life and social capital]. Prešov: Faculty of Philosophy, Prešov University in Prešov.

Babinčák, P. (2008). Definície, teoretické modely a indikátory kvality života. [Definitions, theoretical models and indicators of quality of life]. In V. Bačová (Ed.), Kvalita života a sociálny kapitál. [Quality of life and social capital] (pp. 41-71). Prešov: Faculty of Philosophy, Prešov University in Prešov.

Frahnberg, J. et al. (2001). Dotazník životní spokojenosti. [Life satisfaction questionnaire]. Prague: Testcentrum.

Lukšík, I., Hargašová, L., Kuruc, M., \& Lukšíková, Ĺ. (2014). Vzdelanie, reziliencia a sociálna inklúzia detí z rezidenciálnej starostlivosti. [Education, Resilience and Social Inclusion of Children from Residential Care.] In E. Gajdošová (Ed.), Psychológia - Škola - Inklúzia. [Psychology - School - Inclusion] (pp. 264-271). Bratislava: Faculty of Psychology of PanEuropean University.

Masárová, T. (2012). Kvalita života verzus kvalita sociálnych procesov. [Quality of life versus the quality of social processes]. Sociálno-ekonomická revue. Vedecký časopis. [Socio-Economic Revue. Scientific journal], 10(3), 80-86.

Mcknight, C. G., Huebner, E. S., \& Sueldos, S. (2002). Relationships among stressful life events, temperament, problem behavior, and global life satisfaction in adolescents. Psychology in the Schools, 39(6), 677-687.

Rodný, T., \& Rodná, K. (2001). Dotazník životní spokojenosti. [Life satisfaction questionnaire]. Prague: Testcentrum. 
Súhrnná správa o prieskume dodržiavania základných práv a slobôd maloletých detí umiestnených $v$ reedukačných centrách $v$ Slovenskej republike 2014 [Summary Report on the Survey of Respect for the Fundamental Rights and Freedoms of Minority Children in Reeducation Centers in the Slovak Republic 2014] [online]. Bratislava: Office of the Public Defender of Rights. Retrieved from http://www.vop.gov.sk/files/Sprava\%20VOP\%20 -\%20RC.pdf

Ustawa z dnia 26. października 1982 roku o postępowaniu w sprawach nieletnich (Dz. U. z 1982 roku Nr. 35, poz. 228 późn. zm.) [Law of 26 October 1982 on proceedings in cases of minors] [online]. Warszawa. Retrieved from www.dziennikustaw.gov.pl/D2014000038201.pdf

Zákon č. 245/2008 Z. z. o výchove a vzdelávaní (školský zákon) a o zmene a doplnení niektorých zákonov [Act no. 245/2008 Coll. On education and training (the Education Act) and on the amendment and supplementation of certain laws] [online]. Bratislava: Národná rada slovenskej republiky. Retrieved from https://www.vedatechnika.sk/ SK/.../245_2008_skolsky_zakon.pdf

Žolnová, J., Višňovská, J., \& Majherová, M. (2015). Vnímanie životnej spokojnosti det́mi $\checkmark$ reedukačných centrách. [Perception of life satisfaction in children in reeducation centers]. Prešov: Publishing House of Prešov University.

\section{Authors}

Mgr. Jarmila Žolnová, PhD.

Faculty of Education, University of Prešov in Prešov

Department of Special Education

Ul. 17 novembra 15, 08001 Prešov, The Slovak Republic jarmila.zolnova@unipo.sk

Mgr. Veronika Vaňugová

Faculty of Education, University of Prešov in Prešov

Department of Special Education

Ul. 17 novembra 15, 08001 Prešov, The Slovak Republic veronikavanugova@gmail.com 